\title{
Perspective
}

\section{Labeling of genetically modified food Closer to reality in the United States?}

\author{
Anton E. Wohlers \\ Office of Academic Enrichment \\ Cameron University \\ 2800 W. Gore Blvd. \\ Lawton, OK 73505 \\ awohlers@cameron.edu
}

\begin{abstract}
Within the broader context of several related biotech developments, including the proliferation of GM food in American grocery stories, the recent decision by Whole Foods Market, Inc. to require the labeling of all genetically modified (GM) organism products sold in its stores by 2018 , and the development of GM animals for consumption, this essay asks whether the United States is inching towards a policy of mandatory GM food labeling. The analysis highlights aspects of the biotechnology policy debate in the United States and European Union, and traces public opinion as well as grassroots and legislative efforts aimed at GM food labeling. Findings show that activities at the federal level do not suggest any major regulatory changes regarding labeling in the near future; however, a growing number of individual states are considering GM food labeling legislation and political momentum in favor of labeling has picked up in recent years. Voluntary labeling by food companies may also become increasingly common.
\end{abstract}

Key words: Genetically modified foods, Whole Foods announcement, GM organisms, millions against Monsanto, Proposition 37

I n March of this year, Whole Foods Market, Inc. announced that all genetically modified (GM) organism products sold in Whole Foods stores in the United States and Canada would be labeled by 2018. ${ }^{1}$ This decision, which generated much media attention, comes nearly two decades after the Food and Drug Administration (FDA) first approved the commercialization of a genetically modified food, the Flavr$\mathrm{Savr}^{\mathrm{TM}}$ tomato. The regulatory agency deemed this biotechnology food as beneficial to the consumer and safe for both human consumption and the environment. $^{2,3,4}$ Praising the tomato's "improved shelf-life, processing characteristics, flavor, nutritional properties, and agronomic characteristics" (p. 53), ${ }^{5}$ the FDA also stated that "the intended effect of the altered RNA of the new PG [polygalacturonase] gene that suppresses

doi: 10.2990/32_1_73

the breakdown of pectin in Flavr-Savr ${ }^{\mathrm{TM}}$ tomatoes does not raise safety questions. Pectin is a part of many fruits and is a generally recognized as safe (GRAS) substance." GRAS has paved the way for the United States to emerge as the global leader of commercialized GM crops. ${ }^{6}$ Of the 25 GM crops approved by the FDA, 85 percent of corn, 91 percent of soybeans, and 88 percent of cotton currently produced in the United States are genetically modified. ${ }^{7}$

As a result of this proliferation, an estimated 60 to 80 percent of processed foods in a typical American grocery store contain GM ingredients-almost none of which is labeled. ${ }^{8}$ In contrast to the United States and Canada, more than 60 countries, including Australia, Brazil, China, Russia, South Africa, Turkey, and the 27 members of the European Union, have already implemented mandatory GM food labeling standards according to the Center for Food Safety. ${ }^{9}$ Yet the next 


\section{Woblers}

great leap beyond GM crops is already on the horizon, as the FDA is currently in the final stages of approving the commercialization of the first biotechnology animal-a salmon that grows to maturity twice as fast as its nonmodified cousins. ${ }^{10,11}$

In response to these developments, controversies about GM food and resistance to it have mounted considerably throughout the United States. Similar to concerns raised across countries of the European Union (EU), questions center on whether GM foods present risks and ought to be labeled accordingly. Parallel to the scientific debate about the benefits and risks of GM foods, corporate, grassroots, and state actors are discussing or demanding mandatory labeling of GM foods. Whole Foods Market, Inc. recently announced plans to implement mandatory labeling of GM foods by the year 2018. ${ }^{1}$ Across the U.S., grassroots organizations have organized anti-GM foods campaigns or pressured legislatures to propose mandatory labeling laws. In line with the argument made by Supreme Court Justice Louis Brandeis, who in 1913 wrote that it is time to know what substances we consume, natural food purveyors, activist groups, and policymakers have forcefully renewed the debate on GM food labeling in the generally GM-friendly U.S.

In light of these developments, this essay summarizes the current scientific debate, highlights aspects of biotechnology policy in the United States and EU, and traces public opinion in relation to GM food labeling. It then discusses the role of relevant organized grassroots mobilization and legislative efforts and concludes with some comments on likely future trends. At issue is whether the United States is ready to abandon voluntary GM food labeling and introduce mandatory labeling.

\section{The scientific debate}

The defining characteristic of GM food from the standpoint of biotechnology is the rapid and accurate alteration of genetic material in such a way that does not occur by natural recombination. Most commonly used to genetically alter food for human consumption, GM crops exhibit enhanced traits such as improved nutritional content or increased resistance to herbicide. However, gene transfers are not limited from one crop plant to another. The genetic transfer of the Bacillus thuringiensis (B.t.) gene, a naturally occurring bacteri- um that produces crystal proteins that are lethal to insects, illustrates that this technology also allows for the genetic transfer of non-plant organisms. Owing to the appeal of such genetically induced traits, GM advocates argue that genetic engineering has the potential to lower pesticide use, combat the epidemic hunger crises in developing countries, and strengthen the economies of industrialized countries. However, scientific evidence also suggests that the spread of GM foods jeopardizes nature's biological boundaries causing harm to humans and the environment. With this in mind, the discussion considers the scientific debate in terms of the benefits and dangers of GM foods.

The first generation of GM crops focused on agricultural benefits, such as insect resistance and herbicide tolerance. ${ }^{12}$ Farmers have benefited from planting these crops due to the decreased need for pesticides and herbicides, thereby reducing the release or spread of toxins into the environment or across the human food chain. As scientific progress has continued, the emphasis has also been on enhancing the nutritional content of GM plants and strengthening their ability to grow in different environments-and grow faster. In an effort to counter blindness in children due to pro-vitamin A deficiency prevalent in certain regions of the world, plant scientists in Switzerland funded by the Rockefeller Foundation have created a Golden Rice strain. In addition to improved carotenoids content, this rice produces an enhanced amount of pro-vitamin A. Similarly, GM rice has also been altered in such a way to counter iron deficiency. By altering its genome through the insertion of a gene from the Aspergillus niger fungus, so-called Iron Rice exhibits increased iron content. ${ }^{13}$

In addition to the nutritional benefits derived from GM crops, researchers have also focused on making plants more adaptable to harsh environments. In a world of scarce and rapidly depleting food resources, efforts are underway to increase the food supply by creating GM crops that are able to thrive in environments characterized by harmful soil salinization, drought, heat, and cold. A GM tomato, altered by a gene from a mustard plant, can grow in salty and desalinized soil. Beyond the genetic alterations of crops, biotechnology animals are about to become reality. The Enviropig is designed to better digest phosphates and reduce feed expenditures, while a genetically enhanced hybrid salmon is being developed 


\section{GM food labeling}

that grows much faster than nonmodified salmon. ${ }^{14}$ The growth period for commercialization of the AquAdvantage Salmon, deemed by Aqua Bounty Technologies as environmentally safe, is cut in half by inserting a gene from the Chinook salmon into the conventional Atlantic salmon fish genome. ${ }^{15}$ On the basis of the FDA's preliminary 2012 assessment report that of AquAdvantage has no significant impact on the environment, almost 30,000 comments were submitted to the agency prior to the extension of the public comment period in February of this year. ${ }^{16}$ Despite this strong comment period and disputes about the safety of bio-enhanced fish among scientists, members of Congress, and food advocates, the agency is likely to approve the first GM animal for commercial consumption in the United States later this year. ${ }^{17,18,19}$

The scientific concerns about GM foods tend to fall into three categories: 1) environmental hazards; 2) human health risks; and, 3) socioeconomic dangers. With regard to the spread of GM crop pollen to other fields and subsequent unintended harm to other organisms, a 1999 study by Losey, Raynor, and Carter found that B.t. corn pollen kills monarch butterfly caterpillars. ${ }^{20}$ However, the research was criticized for being improperly conducted and withdrawn. Controversy soon followed and researchers questioned the scientific underpinnings of the study. ${ }^{21}$ Other researchers did not find a relationship between mortality of swallowtail butterfly larvae and the consumption of B.t. pollen. ${ }^{22}$ Parallel to this dispute about harm to other organisms, environmental concerns regarding GM crops have focused on the reduced effectiveness of pesticides, emergence of herbicide-resistant weeds, and soil contamination. Specifically, scientists warn that insects could become resistant to B.t. or other crops, the transfer of herbicide resistant genes to other plants could result in "super weeds," and the toxins produced by GM crops could alter and subsequently harm the soil ecosystem. ${ }^{23}$

Certain foods, like cow's milk, eggs, fish, shellfish, tree nuts, wheat, peanuts, and soybeans, commonly cause allergic reactions. Some of these, including peanuts and tree nuts, may encourage the development of allergies in infants or young children and are associated with life-threatening conditions. Characterized by a relatively immature immune system, children seem to be at greater risk for such allergens than adults. Indeed, the "potentially widespread use of GM food products as food additives and staple foods, including use of baby foods, may lead to earlier introduction of these novel proteins to susceptible infants either directly or via the presence of the maternally ingested protein in breast milk" (p. 58). ${ }^{24}$

The incorporation of a gene from Brazil nuts into soybeans illustrates the possibility of heightened allergic reactions to GM foods in susceptible individuals. In one study, people with common nut allergies experienced a significant allergic reaction to the nutritionally enhanced soybeans. ${ }^{25}$ Similar to the Brazil nut gene, which is known to the scientific community as an allergen, GM peas that expressed a greenbean protein intended to protect against weevils, unexpectedly also caused a number of unintended allergic reactions in mice tests. ${ }^{26}$

Finally, critical voices have also raised socioeconomic concerns. Within the broader context of the postmaterial values movement of the $1960 \mathrm{~s}$ and 1970 s, some stress the negative sociological externalities of biotechnology, including the commodification of life and the increased potential for inequality. ${ }^{27}$ Since bringing a GM food to market may be a lengthy and costly process for corporations, which need to recoup their investment, consumer advocates have expressed concerns that small farmers will not be able afford GM seeds. The major patenting efforts and monopolization of these seeds by "Big Agra" is likely to increase GM seed prices, thereby disadvantaging small farmers, especially across developing countries whose populations are also suffering from food hunger. ${ }^{28}$ Currently, the big seven biotechnology seed companies-Monsanto, DuPont/Pioneer Hi-Bred, Syngenta, Group Limagrain, Land O'Lakes/Winfield Solutions, KWS AG, and Bayer-control 71 percent of the world seed market and account for about $\$ 50$ billion per annum in sales of seeds. To maintain their market monopoly, these companies have entered into mutually beneficial alliances by agreeing to "cross-license proprietary germplasm and technologies, consolidate $\mathrm{R} \& \mathrm{D}$ efforts, and terminate costly patent litigation battles" (p. 10). ${ }^{29}$

Founded by John Francis Queene in 1901, Monsanto has become the world's largest seed company, owning 27 percent of the worldwide seed market. By buying off smaller seed companies, entering into cross-license agreements with other seed companies, and taking advantage of weak antitrust law enforcement and 


\section{Woblers}

favorable decisions rendered by United States courts, Monsanto has managed to dominate the domestic market. More than 80 percent of corn and more than 90 percent of soybeans planted in the United States contain GM traits patented by Monsanto. ${ }^{30}$ This monopolistic dominance continues to have troubling spillover effects on seed prices and patenting. According to the Center for Sustaining Agriculture and Natural Resources, Monsanto's Roundup Ready2 soybean seeds jumped from about $\$ 30$ per bag in 2001 to $\$ 70$ per bag in 2011-a 143 percent increase. ${ }^{30}$ Litigation over patent enforcement is becoming more visible and complicated, as illustrated by recent cases where farmers involuntarily grew Monsanto-engineered strains or planted descendents of the company's GM seeds.

As courts continue to weigh the legal arguments, the introduction of a "suicide gene" into GM plants may be the preferred solution of the corporate world. Viable for only one growing season, these GM plants would produce sterile seeds that do not germinate. However, farmers would be required to invest in fresh supplies of seeds each year, thereby creating precarious financial situations and disadvantageous dependencies for farmers. $^{31}$

\section{The policy debate}

Since the invention of biotechnology in 1973, policy debates have persisted in the United States and across the countries of the European Union. Characterized by expert consensus, the early period of biotechnology developments and advancements emphasized government oversight and the pursuit of regulatory frameworks or language from a precautionary perspective. Accordingly, the United States adopted the Coordinated Framework in 1986 and the European Council recommended a national registration of biotechnology activities. However, increasingly divergent regulatory paths on both sides of the Atlantic became visible by the mid-1980s and entrenched during the 1990s. ${ }^{32}$ In 1986, a watershed year, the Organization for Economic Cooperation and Development (OECD) released its Recombinant DNA Safety Considerations (Blue Book) and the Danish government adopted the first national biotechnology legislation, the Gene Technology Act. During the 1980s, the European Commission announced the intention to create a regulatory frame- work for biotechnology, and the United States continued to deem the substantial equivalence concept $^{33}$ as adequate to assess and justify the minimal risks of modern biotechnology. ${ }^{34}$ Defined by the Organization of Economic Cooperation and Development, the concept of substantial equivalence "embodies the idea that existing organisms used as foods, or as a source of food, can be used as the basis for comparison when assessing the safety of human consumption of a food or food component that has been modified or is new" (p. 14). ${ }^{33}$

In the 1990s and 2000s, as the bovine spongiform encephalopathy (or "Mad Cow" disease) scandal unfolded in the United Kingdom and Monsanto's genetically modified Roundup Ready arrived in European harbors mixed with conventional soybeans, the EU adopted a series of directives that focused on the deliberate release of GM organisms into the environment. In doing so, the EU continued to move towards an increasingly stringent regulatory framework for biotechnology. Aimed at protecting human health and the environment from potential harms from GM organisms, the EU, in contrast to the United States, fortified its precautionary regulatory framework with the adoption in 2001 of Directive 2001/18 on the deliberate release of GM organisms into the environment. Along with other directives, 2001/18 introduced a series of stringent demands ranging from the development of a common risk assessment methodology to the call for research on potential risk and the need for GM product traceability and labeling. Labeling of GM products became a regulatory reality with the passage of a host of different instruments, including Regulation 1829/2003. Based on a 0.9 percent threshold and excluding products such as meat, milk, and eggs obtained from animals that have consumed GM feed, this regulation requires the mandatory labeling of GM feed and food. ${ }^{35}$

Though Regulation 1829/2003 remains the guiding labeling policy across the EU, additional regulatory limitations on GM organisms within the EU and other related policies have been initiated by individual member states. The EU has ratified the Cartagena Protocol on Biosafety, an international agreement designed to ensure the safe transfer and handling of GMO crops, and adopted Regulation 1946/2003 on transboundary movements of genetically modified organisms. In recent years, European consumers have 


\section{GM food labeling}

Table 1. Global area (in million hectares) of GM crops in $2012^{58}$

\begin{tabular}{|c|c|c|c|}
\hline Rank & Country & Area & GM Crops \\
\hline 1 & USA & 69.5 & Maize, soybean, cotton, canola, sugarbeet, alfalfa, papaya, squash \\
\hline 2 & Brazil & 36.6 & Soybean, maize, cotton \\
\hline 3 & Argentina & 23.9 & Soybean, maize, cotton \\
\hline 4 & Canada & 11.6 & Canola, maize, soybean, sugarbeet \\
\hline 5 & India & 10.8 & Cotton \\
\hline 6 & China & 4.0 & Cotton, papaya, poplar, tomato, sweet pepper \\
\hline 7 & Paraguay & 3.4 & Soybean, maize, cotton \\
\hline 8 & South Africa & 2.9 & Maize, soybean, cotton \\
\hline 9 & Pakistan & 2.8 & Cotton \\
\hline 10 & Uruguay & 1.4 & Soybean, maize \\
\hline 11 & Bolivia & 1.0 & Soybean \\
\hline 12 & Philippines & 0.8 & Maize \\
\hline 13 & Australia & 0.7 & Cotton, canola \\
\hline 14 & Burkina Faso & 0.3 & Cotton \\
\hline 15 & Myanmar & 0.3 & Cotton \\
\hline 16 & Mexico & 0.2 & Cotton, soybean \\
\hline 17 & Spain & 0.1 & Maize \\
\hline 18 & Chile & $<0.1$ & Maize, soybean, canola \\
\hline 19 & Columbia & $<0.1$ & Cotton \\
\hline 20 & Honduras & $<0.1$ & Maize \\
\hline 21 & Sudan & $<0.1$ & Cotton \\
\hline 22 & Portugal & $<0.1$ & Maize \\
\hline 23 & Czech Republic & $<0.1$ & Maize \\
\hline 24 & Cuba & $<0.1$ & Maize \\
\hline 25 & Egypt & $<0.1$ & Maize \\
\hline 26 & Costa Rica & $<0.1$ & Cotton, soybean \\
\hline 27 & Romania & $<0.1$ & Maize \\
\hline 28 & Slovakia & $<0.1$ & Maize \\
\hline
\end{tabular}

become increasingly interested in whether GM feed has been used in the production cycle of food. In response, countries like Austria, Germany, and France have implemented national policies to promote the consistent labeling of food produced without GM technology. Recently, the European Commission has launched a formal review process to determine the usefulness of an EU-wide voluntary scheme for GM-free labeling, considered by some countries as unnecessary and even confusing to consumers. ${ }^{36}$

As countries across the EU have delayed or blocked the release of GM crops, others have witnessed a sharp rise of GM crops. In 2002, 16 countries grew GM crops on 145 million acres of farmland. Ten years later, the number of countries growing such crops has increased to 28 and the total acreage currently covered with GM crops stands at 420 million acres of land. Almost equivalent to the size of Alaska, this represents a record high according to the International Service for the Acquisition of Agri-biotech Applications, an industry trade group. As illustrated by Table 1, the United States clearly leads in terms of both the area and number of GM crops, followed by Brazil and
Argentina. With a total area of 69.5 million hectares devoted to GM crops, compared to 36.6 million hectares in Brazil, 23.9 million hectares in Argentina, and $\mathbf{1 1 . 6}$ million hectares in Canada, the United States plants a relatively wide variety of genetically modified foods, including maize, soybean, cotton, canola, sugarbeet, alfalfa, papaya, and squash. This is in stark contrast to a few European countries like Spain, the Czech Republic, and Slovakia that have only permitted the planting of GM maize on 0.1 million hectares or less within each country.

Under constant lobbying pressure by multinational agricultural biotechnology corporations, the United States remains the strongest advocate of GM crop dissemination of any industrialized country and endorses minimal regulatory interference, especially with respect to labeling. The FDA, charged with protecting and promoting public health through the regulation and supervision of food safety and other products, continues to follow its original 1992 policy and believes that "the method of development of a new plant variety (including the use of new techniques including recombinant DNA techniques) is normally 


\section{Woblers}

material information within the meaning of 21 U.S.C. $321(\mathrm{n})$ and would not usually be required to be disclosed in labeling for the food." ${ }^{2}$ Within the context of the substantial equivalence principle and the lack of data that would make it necessary to disclose GM foods, the FDA is convinced that the labeling of GM foods would be misleading and promote the cluttering of food labels. Unless there is scientific evidence that GM foods pose material novel risks, the agency, as of January 2001, continues to reaffirm "its decision to not require special labeling of all bioengineered foods." 37

The FDA's understanding of GM labeling has not gone unchallenged. In 1998, Alliance for BioIntegrity, a nonprofit, nonpolitical organization dedicated to the advancement of human and environmental health through sustainable and safe technologies, brought together interest groups, religious leaders, and scientists to file a lawsuit before the United States District Court in Washington, DC against the FDA's policy on GM foods. They argued that widespread consumer interest in favor of GM food labeling should be taken into consideration by the FDA given its charge to protect and promote public health. Despite the claim, the district court in Alliance for Bio-Integrity $v$. Shalala rejected all plaintiff arguments stating that the plaintiffs do not understand the limited authority of FDA to consider consumer demand for labeling. In fact, the FDA does not have the regulatory authority to require such labeling because "special labeling for genetically engineered foods is not required under section 201(n) of the [Federal Food, Drug, and Cosmetic] Act if the sole justification for such a requirement is consumer demand." "38 Furthermore, the court held that GM foods do not differ substantially from conventional food products. Hence, the court concluded that consumer demand was not sufficient for requiring GM food labeling. ${ }^{39}$

Regardless of regulatory authority and the substantial equivalence principle, those in opposition to mandatory labeling argue that it would be impractical to draw a clear line between GM foods and their conventional counterparts and that such a requirement would increase costs for consumers due to testing for the segregation of crops, enforcement of labeling regulations, and presence of GM ingredients. $^{40,41}$

\section{Public opinion, grassroots mobilization, and legislative efforts}

In the U.S., activities at the federal level do not suggest any major regulatory changes regarding GM food labeling in the near future. For many years, former Democratic Representative Dennis Kucinich of Ohio introduced legislation entitled the "Genetically Engineered Food Right to Know Act." ${ }^{41}$ Kucinich's legislative overtures failed but others have continued to champion the idea. In the fall of 2011, the Center for Food Safety filed a citizen petition with the FDA. ${ }^{42}$ The petitioners declared that, "the absence of mandatory labeling disclosures for GE [genetically engineered] foods is misleading to consumers. FDA's failure to require labeling for GE foods is an abdication of its statutory mandate to require labeling for foods that are 'misbranded' because they are misleading" (p. 2). ${ }^{43}$ Garnering 850,000 signatures by March 2012-and thus more signatures than any other federal food petition-the petition and its demand to rescind the FDA's 1992 Statement of Policy: Food Derived from New Plant Varieties has not triggered any changes in regulatory attitude. ${ }^{11}$ Neither has the fact that over 1 million people have asked the FDA to label GM food. ${ }^{44}$ Though the FDA "recognize[s] and appreciate[s] the strong interest that many consumers may have in knowing whether a food was produced using genetic engineering, [it] supports voluntary labeling for food derived from genetic engineering." 45

Another recent attempt to change the federal course on GM food labeling took place in the summer of 2012. Independent Senator Bernie Sanders from Vermont and Democratic Senator Barbara Boxer from California proposed an amendment to the farming bill that would "[p]ermit States to require that any food, beverage, or other edible product offered for sale have a label on indicating that the food, beverage, or other edible product contains a genetically engineered ingredient." 46 The amendment failed to pass by a vote of 26 to 73 . Though these reactions at the federal level are not supportive of GM food labeling efforts, public opinion polls, grassroots mobilization, and legislative efforts at the state level suggest an emerging and increasingly deepening political will to embrace GM labeling. As indicated by Figure 1, there has been consistent and strong public support for mandatory labeling of GM foods since the 1990s. For more than 


\section{GM food labeling}

two decades, representative public opinion polls that ask whether GM foods should be labeled show an overwhelming majority of respondents in favor of it. Favorable responses range from 86 percent to 96 percent. Despite some decline of support for GM food labeling in 2000 and 2012, an average of 91 percent of those polled in the U.S. since 1992 have been in favor of GM food labeling.

Frustrated by the FDA's unyielding position on GM food labeling, grassroots organizations have mobilized across the country to defend consumers' right to know what they are buying. Grassroots groups most often invoke the right to know argument in favor of GM food labeling and in other cases encourage individual consumers to take local action and label GM foods in grocery stores and supermarkets like the Label It Yourself campaign. ${ }^{47}$ In addition to encouraging such labeling campaigns or "guerilla stickering," as it is called by some, these grassroots organizations are having a gradual influence on policymaking-and corporate behavior. As suggested by Table 2, these decentralized efforts aimed at advocating GM food labeling fall into three broad categories. With a footing in more than 30 states, Millions Against Monsanto, a project of the online nonprofit Organic Consumer Association based in Minnesota, is the most prominent organized grassroots GM labeling group in the U.S. and has been actively involved in changing the legislative course at the state level. ${ }^{48}$

Grassroots pressure from these organizations continues to make inroads into the public policymaking process. By a margin of 48.6 percent in favor of GM labeling and 51.4 percent against it, advocacy groups like Just Label It Campaign and Yes on 37 came close to winning passage of Proposition 37 in California last November despite coordinated efforts and generous donations to the No 37 campaign. As expected, campaign contributions to the No 37 campaign-totaling \$32 million-came from major food and agricultural trade groups, including Monsanto (\$7.1 million), DuPont ( $\$ 4.9$ million), Dow (\$2 million), and PepsiCo (\$1.7 million). ${ }^{49}$ Their opponents raised a mere $\$ 4$ million but lost only by a narrow margin. If California's statewide ballot initiative had passed, the Right to Know Genetically Engineered Food Act would have required the labeling of any genetically engineered agricultural commodity or food containing GM ingredients. ${ }^{50}$ In doing so, California would have clearly surpassed any

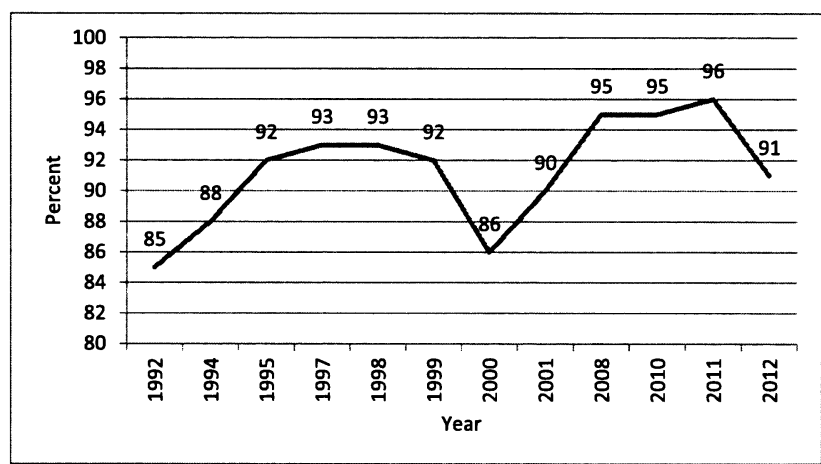

Figure 1. U.S. public support for GM food labeling, 1992 to $2012^{58}$

current state or international laws in its labeling requirements. Currently, Alaska is the only state in the union that requires GM food labeling; in 2005, lawmakers there enacted legislation requiring labeling for bioengineered fish-a GM food that has not yet been marketed. ${ }^{51}$ In terms of reporting requirements, California's Proposition 37 would have applied "the strictest threshold level for unintentional traces of GM ingredients of any international mandatory labeling scheme, including that of the European Union (EU) where the threshold is $0.9 \%$ for adventitious [accidental] presence of GM." 52

Yet, the narrow defeat of Proposition 37 has spurred grassroots and legislative actions across the country and has caught the attention of major food companies. In Washington state, a grassroots campaign is underway in support of Initiative 522, the People's Right to Know Genetically Engineered Food Act. On the ballot in November 2013 and modeled after Proposition 37, this act would require GM organisms to be labeled statewide. Based on aggregated data from all 50 states reported in Open States, ${ }^{53}$ a searchable online database sponsored by the Sunlight Foundation, legislative momentum in favor of GM food labeling is becoming increasingly widespread across the states.

In 2009, only one state, Illinois, considered legislation regarding GM food labeling. A few years later, the number of states pursuing such legislation had increased to 12. During the 2012-2013 legislative session, more than 20 states, mostly in the Northeast and West, considered legislation requiring the labeling of GM foods (see Figure 2). Currently, 18 states are actively pursuing such legislation, including Illinois, 


\section{Woblers}

Table 2. Major grassroots organizations advocating GM food labeling by state

\begin{tabular}{ll}
\hline \hline Grassroots organization & \multicolumn{1}{c}{ State } \\
\hline Millions Against Monsanto & $\begin{array}{c}\text { Alabama, Alaska, Arkansas, Delaware, Indiana, Iowa, Florida, Georgia, Kansas, Kentucky, Louisiana, Maine, } \\
\text { Maryland, Massachusetts, Minnesota, Mississippi, Missouri, Nebraska, Nevada, New Hampshire, New }\end{array}$ \\
& Jersey, New Mexico, North Carolina, Oklahoma, Oregon, Pennsylvania, Rhode Island, South Carolina, \\
& South Dakota, Tennessee, Vermont, Virginia, Washington, West Virginia, Wyoming \\
Arizona, Colorado, Connecticut, Florida, Georgia, Idaho, Illinois, Massachusetts, New Jersey, New York, \\
GMO Free & Ohio, Oregon, Utah \\
Label GMO / Just Label It & California, Florida, Hawaii \\
Right to Know & Connecticut, Illinois, Minnesota \\
\hline
\end{tabular}

Iowa, and Missouri in the Midwest. However, constitutional challenges on the grounds of commercial speech protection provided by the First Amendment and a legal precedent set by the Supreme Court in its 1980 Central Hudson Gas \& Electricity Corp. v. Public Service Commission of New York ruling remain formidable barriers to GM labeling regulations, as suggested by the successful litigation against labeling laws in Vermont and Ohio. ${ }^{54}$ In the Central Hudson Gas ruling, the Supreme Court laid out a four-part test for determining when restrictions on commercial speech violated First Amendment protections. To determine whether commercial speech can be banned for the purpose of promotional advertising, the fourstep analysis focuses on whether: 1) Is the expression protected by the First Amendment? 2) Is the asserted governmental interest substantial? 3) Does the regulation directly advance the governmental interest asserted? and, 4) Is the regulation more extensive than is necessary to serve that interest?

Given the grassroots efforts and legislative activities at the state level, it seems that the demand for GM food labeling in the U.S. has never been more visible. Moreover, it is clear that these activities in favor of GM food labeling have also caught the attention of Big Agra and the major food companies. In fact, there may be some reconsideration of the industry's hardline stance against labeling in light of the growing grassroots movement and proposed state legislation in favor of GM food labeling. There is no question that many of the major food corporations welcomed the defeat of Proposition 37. However, as pointed out by Jennifer Hatcher, a senior vice president of government and public affairs for the Food Marketing Institute, "we hope we don't have too many of them, because you can't keep doing that over and over again." 55
In response, executives from PepsiCo, ConAgra, Wal-Mart, and other major food companies usually against mandatory GM food labeling, along with advocacy groups that favor such labeling, attended a closed meeting in Washington, DC at the Meridian Institute in January 2013 to weigh mandatory GM food labeling requirements. ${ }^{56}$ Though this meeting may have been just part of a public relations strategy to quell grassroots demand for labeling, the decision by Whole Foods to label all GM products sold in North America by 2018 cannot be easily ignored, either for the message it sends to consumers or from a competitive market perspective. Accordingly, Walter Robb, the company's co-CEO, declared that his company is "putting a stake in the ground on GMO labeling to support the consumer's right to know." 57 Thousands of miles away, Down to Earth, a small chain of natural, all-vegetarian food stores based in Honolulu, announced that it will also require GM ingredient transparency by $2018 .^{58}$

\section{Outlook for the future}

As the scientific community has continued to discuss the benefits of GM crops in terms of both their nutritional content and environmental adaptability and their negative impact on human health and the environment, the public in the United States has become increasingly skeptical and uncertain about GM biotechnology. In response to these concerns, some regulatory adjustments have been proposed, reflecting increasing opposition to GM foods and consistently strong public opinion in favor of labeling. At the same time, however, policymakers within the FDA have not made any fundamental changes to the regulatory framework governing biotechnology applications, while continuing to encourage the advancement of genetically engineered food and opposing the 


\section{GM food labeling}

\begin{tabular}{|l|}
\hline$\cdot$ Enacted legislation \\
\hline$\cdot$ Legislation under consideration \\
\hline$\cdot$ Legislation dead in committee \\
\hline$\cdot$ No legislation \\
\hline
\end{tabular}

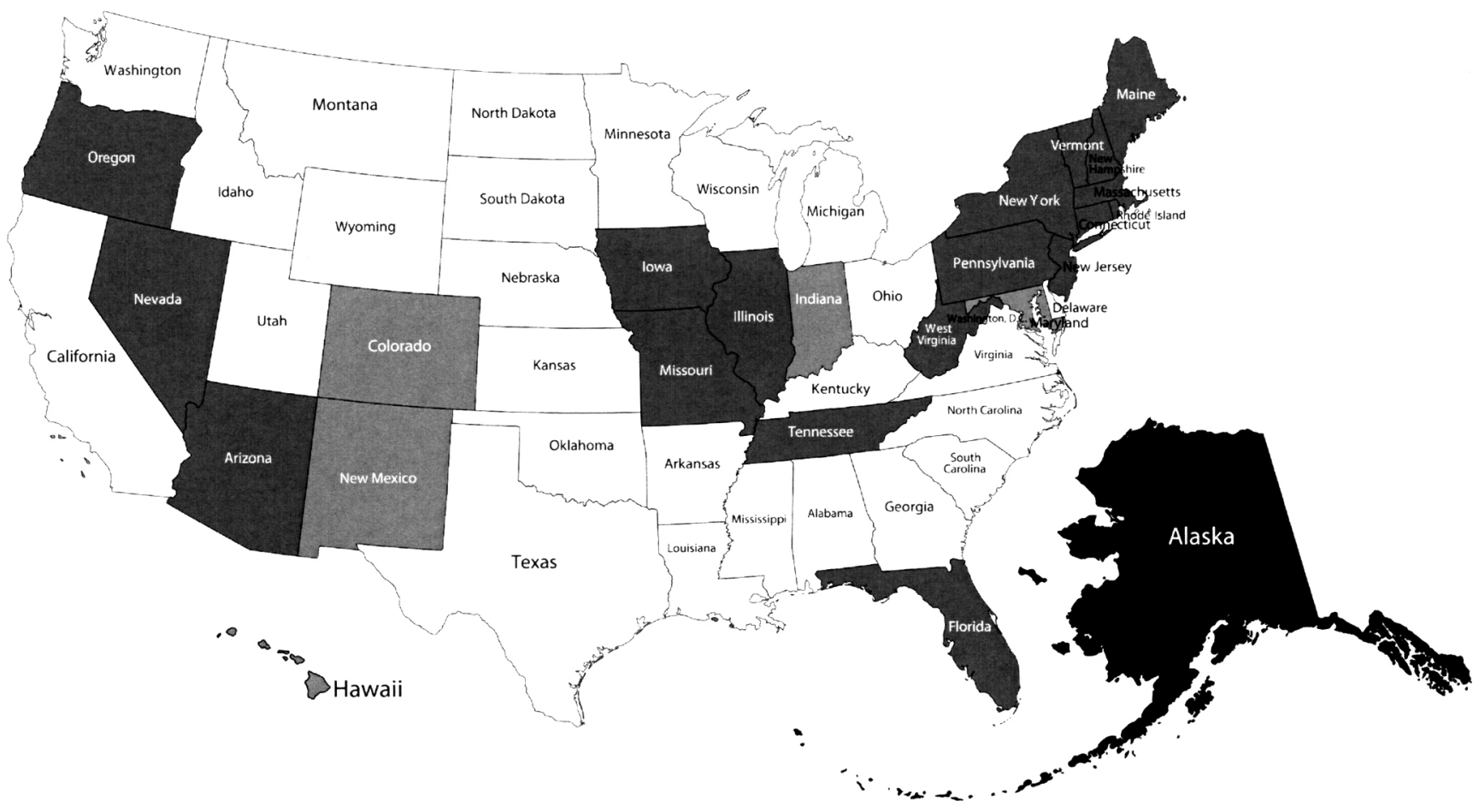

Figure 2. Current status of GM food labeling legislation at the state level

mandatory labeling of GM foods. This regulatory trajectory has been solidified by the Supreme Court in the case of Hudson Gas \& Electricity Corp. v. Public Service Commission of New York and a number of rulings against labeling by state courts based on that legal precedent. In contrast, the EU has remained steadfast in opposition to GM food since the 1990s. Consistent suspicion of GM food as something unnatural coincided with the strengthening of the precautionary principle and the adoption of strict labeling standards across the EU.

As far as the United States is concerned, it seems that the legal barriers are simply too high and the precedents too entrenched for the emergence of a GM food labeling regime at the national level. This trajectory may not be inevitable, however. As illustrated by major education and health care reforms at the national level, policy changes advocated and implemented at the state level can eventually facilitate such changes at the federal level. The widespread activities of grassroots organizations in favor of GM food labeling, combined with their active support of legislative actions, have left visible policy footprints at the state level. The narrow defeat of Proposition 37 in California, the ballot initiative in Washington State, and the legislative proposals in Connecticut, Vermont, New Mexico, and Missouri cannot be brushed away as random or ephemeral attempts to affect policy changes. In fact, legislative momentum in favor of GM food labeling at the state level has picked up in recent years. Currently, more than 15 states concentrated in the West, Midwest, and Northeast are considering such legislation. Hence, one state at a time, parts of the country may be moving closer to 


\section{Woblers}

joining the GM labeling bandwagon-a mounting trend that has not gone unnoticed by the major biotechnology and food corporations and which may accelerate as a result of the likely approval of the first GM animal.

\section{References}

1. Carey Polis, "Whole Foods GMO labeling to be mandatory by 2018," The Huffington Post, March 3, 2013, http:// www.huffingtonpost.com/2013/03/08/whole-foods-gmolabeling-2018_n_2837754.html

2. Food and Drug Administration, "Statement of policy: Foods derived from new plant varieties," 1992 http:// www.fda.gov/Food/GuidanceRegulation/GuidanceDocuments RegulatoryInformation/Biotechnology/ucm096095.htm

3. Food and Drug Administration, Biotechnology of Food, FDA Backgrounder BG94-4, (Washington DC: Center for Food Safety and Applied Nutrition, May 18, 1994).

4. Food and Drug Administration, "First biotech tomato marketed,” FDA Consumer Magazine, 1994 (September): 3-4.

5. Darrell M. West, Biotechnology Policy Across National Boundaries. The Science-Industrial Complex (New York: Palgrave MacMillan, 2007).

6. Clive James, "ISAAA brief 43, global status of commercialized biotech/GM crops: 2011," ISAAA Briefs, February 7, 2012 (Ithaca, New York: International Service for the Acquisition of Agri-biotech Applications), http://www.isaaa. org/resources/publications/briefs/43/

7. Center for Food Safety, About Genetically Engineered Foods, 2013 (Washington, DC), http://www.centerforfoodsafety.org/ issues/311/ge-foods/about-ge-foods

8. P. Byrne, "Labeling of genetically engineered foods," Fact Sheet No. 9.37I. Food and Nutrition Series, September 2010 (Fort Collins: Colorado State University Extension), http:// www.ext.colostate.edu/pubs/foodnut/09371.pdf

9. Center for Food Safety, International Labeling Laws, 2013 (Washington, DC), http://www.centerforfoodsafety.org/ issues/976/ge-food-labeling/international-labeling-laws

10. Katia Moskvitch, "Salmon steak from GM fish could soon be on your plate," BBC News online, January 22, 2013, http://www.bbc.co.uk/news/technology-21078731

11. Georgina Gustin, "Push to label genetically modified food gains steam biotech industry claims tracing ingredients would be complex, costly," St. Louis Post Dispatch, March 3, 2012, http://www.stltoday.com/business/local/ push-to-label-genetically-modified-food-gains-traction/ article_397471e6-625a-11e1-a317-001a4bcf6878.html

12. Nina Fedoroff, "Genetically modified foods: Making the Earth say beans," Science Journal, 2007 (Spring): 1-5.
13. A. Pandey, M. Kamle, L. P. Yadava, M. Muthukumar, P. Kumar, V. Gupta, M. Ashfaque, and B.K. Pandey, "Genetically modified food: Its users, future prospects and safety assessments." Biotechnology, 2011 (9): 444-458.

14. Michael Bennett Homer, "Frankenfish, it's what's for dinner: The FDA, genetically engineered salmon, and the flawed regulation of biotechnology," Columbia Journal of Law and Social Problems, 2012 (45): 90-91.

15. Aqua Bounty Technologies, "Environmental assessment for AquAdvantage Salmon. An Atlantic salmon (Salmo salar $L$.) bearing a single copy of the stably integrated $\alpha$-form of the opAFP- GHc 2 gene construct at the $\alpha$-locus in the EO1 aline," August 25, 2010, http://www.fda.gov/downloads/ AdvisoryCommittees/CommitteesMeetingMaterials/ VeterinaryMedicineAdvisoryCommittee/UCM224760.pdf

16. Dene Moore, "Tens of thousands of comments come into U.S. FDA on Canadian GM salmon." Canadian Press, February 13, 2013, http://www.canada.com/technology/ Tens+thousands+comments+come+into+Canadian+salmon/ 7959963/story.html

17. Food and Drug Administration, "Draft environmental assessment and preliminary finding of no significant impact concerning a genetically engineered Atlantic salmon," Federal Register, December 26, 2012 (77): 76050. http://www.gpo. gov/fdsys/pkg/FR-2012-12-26/pdf/2012-31118.pdf

18. Igor I. Solar, "FDA: Genetically modified salmon may be approved in 2013," Digital Journal, May 7, 2013, http:// digitaljournal.com/article/349660

19. Jocelyn C. Zuckerman, "Catch of the day: Transgenic salmon? Not so fast," The Huffington Post, May 6, 2013, http://www.huffingtonpost.com/onearth/catch-of-the-daytransgen_b_3224374.html

20. John E. Losey, Linda S. Raynor, and Maureen E. Carter, "Transgenic pollen harms Monarch larvae," Nature, 1999 (399): 214.

21. Anthony M. Shelton and Mark K. Sears, "The Monarch butterfly controversy: Scientific interpretations of a phenomenon," The Plant Journal, 2001 (27): 483-488.

22. C. I. Wraight, A.R. Zangeri, M. J. Carroll, and M.R. Berenbaum, "Absence of toxicity of Bacillus thuringiensis pollen to black swallowtails under field conditions," Proc. Natl. Acad. Sci. USA, 2000 (97): 7700-7703.

23. Maria Alice Garcia and Miguel A. Altieri, "Transgenic crops: Implications for biodiversity and sustainable agriculture," Bulletin of Science, 2005 (25): 335-353.

24. The Royal Society of Canada, "Elements of precaution: Recommendations for the regulation of food biotechnology in Canada," January 2001 (Ottawa, Canada), http://www. canadians.org/food/documents/rsc_feb05.pdf

25. Julie A. Nordlee, Steve L. Taylor, Jeffrey A. Townsend, 


\section{GM food labeling}

Laurie A. Thomas, and Robert K. Bush, "Identification of a brazil nut allergen in transgenic soybeans," New England Journal of Medicine, 1996 (334): 688.

26. Katharina A. Van Tassel, "Genetically modified plants used for food. Risk assessment and uncertainty principles: Does the transition from ignorance to indeterminacy trigger the need for post-market surveillance?" Boston University Journal of Science and Technology Law, 2009 (15): 220-251.

27. W. A. Munro and R. A. Schurman, "Sustaining outrage: Cultural capital, strategic location and motivating sensibilities in the U.S. anti-genetic engineering movement," in Wynne Wright and Gerad Middendorf, eds., The Fight Over Food: Producers, Consumers, and Activists Challenge the Global Food System (University Park, PA: Pennsylvania State University Press, 2008), pp. 145-176.

28. Lisa H. Wiesel, Food Fray: Inside the Controversy Over Genetically Modified Food (New York: American Management Association, 2009).

29. Hope Shand, "The big six: A profile of corporate power in seeds, agrochemicals and biotech," The Heritage Farm Companion, 2012 (Summer): 10-15, www.seedsavers.org/ site/pdf/HeritageFarmCompanion_BigSix.pdf

30. Ken Roseboro, "The GMO cartel," The Organic \& NonGMO Report, February 1, 2013, http://www.non-gmoreport. com/articles/february2013/the-gmo-seed-cartel.php

31. Charu Verma, Surabhi Nanda, R.K. Singh, R.B. Singh, and Sanjay Mishra. "A review on impacts of genetically modified food on human health," Open Nutraceuticals Journal, 2011 (4): 3-11.

32. L. Levidow, S. Carr and D. Wield, "Genetically modified crops in the European Union: Regulatory conflict and precautionary opportunities," Journal of Risk Research, 2000 (3): 189-208.

33. Organization of Economic Cooperation and Development (OECD), Safety Evaluation of Foods Derived by Modern Biotechnology. Concepts and Principles (Paris: Organization of Economic Cooperation and Development, 1993).

34. Mark Cantley and Maurice Lex, "Genetically modified foods and crops," in Jonathan B. Wiener, Michael D. Rogers, James K. Hammitt, and Peter H. Sand, eds., The Reality of Precaution: Comparing Risk Regulation in the United States and Europe (New York: Earthscan, 2011), pp. 39-64.

35. European Union, "Regulation (EC) no. $1829 / 2003$ of the European Parliament and of the Council of 22 September 2003 on genetically modified food and feed," Official Journal of the European Union, http://ec.europa.eu/food/food/ animalnutrition/labelling/Reg_1829_2003_en.pdf

36. Food Standards Agency, "Short consultation: EU harmonisation of 'GM-free' labeling," January 30, 2013
(London, UK), http://www.food.gov.uk/multimedia/pdfs/ gm-labelling-short-consultation.pdf

37. Food and Drug Administration, "Guidance for industry: Voluntary labeling indicating whether foods have or have not been developed using bioengineering," January 2001 (Washington, DC) http://www.fda.gov/Food/GuidanceRegulation/ GuidanceDocumentsRegulatoryInformation/LabelingNutrition/ ucm059098.htm

38. Food and Drug Administration, "Inspections, compliance, enforcement, and criminal investigations. Court updates and other enforcement activities 2001," August 7, 2003 (Washington, DC), http://www.fda.gov/ICECI/EnforcementActions/ EnforcementStory/EnforcementStoryArchive/ucm109493.htm

39. Lauren Zeichner, "Product vs. process: Two labeling regimes for genetically engineered foods and how they relate to consumer preference," Environs, 2002-03 (27)2: 482-483.

40. Wallace E. Huffman, "Production, identity preservation, and labeling in a marketplace with genetically modified and non-genetically modified foods," Plant Physiology, 2004 (134): 3-10.

41. Gary E. Merchant, Guy A. Cardineau, and Thomas P. Redick, Thawing Consumer Choice. The Case Against Mandatory Labeling for Genetically Modified Foods (Washington, DC: American Enterprise Institute, 2010).

42. Colin O'Neil, "Consumers call on FDA to label GE foods," Gene Watch, 2011 (October-November): 31-33.

43. Center for Food Safety, "Citizen petition before the U.S. Food and Drug Administration," 2011 (Washington, DC), http://justlabelit.org/wp-content/uploads/2011/09/ gelabelingpetition.pdf

44. Ellen Moyer, "Telling the truth about food ingredients helps the consumer, the economy and the environment," The Huffington Post, February 6, 2013, http://www.huffingtonpost. com/ellen-moyer-phd/gmo-labeling_b_2619074.html?ir=Food

45. Food and Drug Administration, "Foods derived from genetically engineered plants," April 8, 2013 (Washington, DC), http://www.fda.gov/Food/FoodScienceResearch/ Biotechnology/ucm 346858.htm

46. The Library of Congress, Bill Summary $\&$ Status. $112^{\text {th }}$ Congress (2011-2012) S. AMDT. 2310, http://thomas.loc. gov/cgi-bin/bdquery/z?d112:sp2310:

47. Label It Yourself, http://labelityourself.org/about

48. Organic Consumer Association, Campaigning for Health, Justice, Sustainability, Peace, and Democracy (Finland, MN), http://organicconsumers.org/

49. Tom Philpott, "Could the election kill Monsanto's mutant seeds?" Mother Jones 2012 (37): 6, http://www. questia.com/library/1P3-2787097341/could-this-electionkill-monsanto-s-mutant-seeds 


\section{Woblers}

50. Claire Mitchell and Stoel Rives, "California's GE labeling ballot initiative could be a game changer," Guide to U.S. Food Labeling Law, 2012 (August): http://www.stoel. com/files/Mitchell_food2012-08.pdf

51. Alaska State Legislature, "Relating to labeling and identification of genetically modified fish and fish products," $24^{\text {th }}$ Legislature (2005-06), http://www.legis.state.ak.us/ basis/get_bill_text.asp?hsid=SB0025Z\&session $=24$

52. A. Colin, Guillaume Carter, P. Grure, Patrick McLaughlin, and Matthew MacLachlan, "California's Proposition 37: Effects of mandatory labeling of GM food," Giannini Foundation of Agricultural Economics, 2012, http://giannini.ucop.edu/media/are-update/files/articles/ V15N6_2.pdf

53. Sunlight Foundation, Open States: Discover Politics in Your State, http://openstates.org/
54. Jonathan H. Adler, "How not to label biotech foods," The New Atlantis 2012 (Summer): 39-42.

55. Ronnie Cummings, "Are Walmart and big food lobbying for a GMO law?" AlterNet, January 10, 2013, http://www. alternet.org/food/are-wal-mart-and-big-food-lobbying-fdagmo-labeling-law

56. Stephene Strom, "Genetic changes to food may get uniform labeling," New York Times, January 31, 2013, http://www.nytimes.com/2013/02/01/business/foodcompanies-meet-to-weigh-federal-label-for-geneengineered-ingredients.html? pagewanted $=$ all $\& \_r=1 \&$

57. Cookson Beecher, "Whole Foods to require labeling of GMO foods," Food Safety News, March 15, 2013, http:// www.foodsafetynews.com/2013/03/whole-foods-torequire-labeling-of-gmo-foods/\#.UYXL4kpKXDs

58. Julie Gallagher, "Industry reacts to mandate," Supermarket News, 2013 (61): 1-2. 